TITLE:

\title{
NOTES ON SOME ANIMAL \\ PLANKTONS COLLECTED FROM \\ THE SEA OF JAPAN OFF SAN'IN- DISTRICT
}

AUTHOR(S):

Furuhashi, Kenzo

\section{CITATION:}

Furuhashi, Kenzo. NOTES ON SOME ANIMAL PLANKTONS COLLECTED FROM THE SEA OF JAPAN OFF SAN'IN-DISTRICT. PUBLICATIONS OF THE SETO MARINE BIOLOGICAL LABORATORY 1952, 2(2): 257-260

ISSUE DATE:

1952-10-05

URL:

http://hdl.handle.net/2433/174676

RIGHT: 


\title{
NOTES ON SOME ANIMAL PLANKTONS COLLECTED FROM THE SEA OF JAPAN OFF SAN'IN-DISTRICT
}

\author{
KENZÔ FURUHASHI \\ Maizuru Marine Observatory, Maizuru
}

\section{With a Map and 2 Tables}

Severa1 plankton samples were collected by the R.M.S. "Kuroshio-maru" of Maizuru Marine Observatory at a station in the Sea of Japan 20 miles off Kasumi, a little town in San'in district shown in the map, in May of 1951. Examining this material, I found a great number of cold water plankton ani-

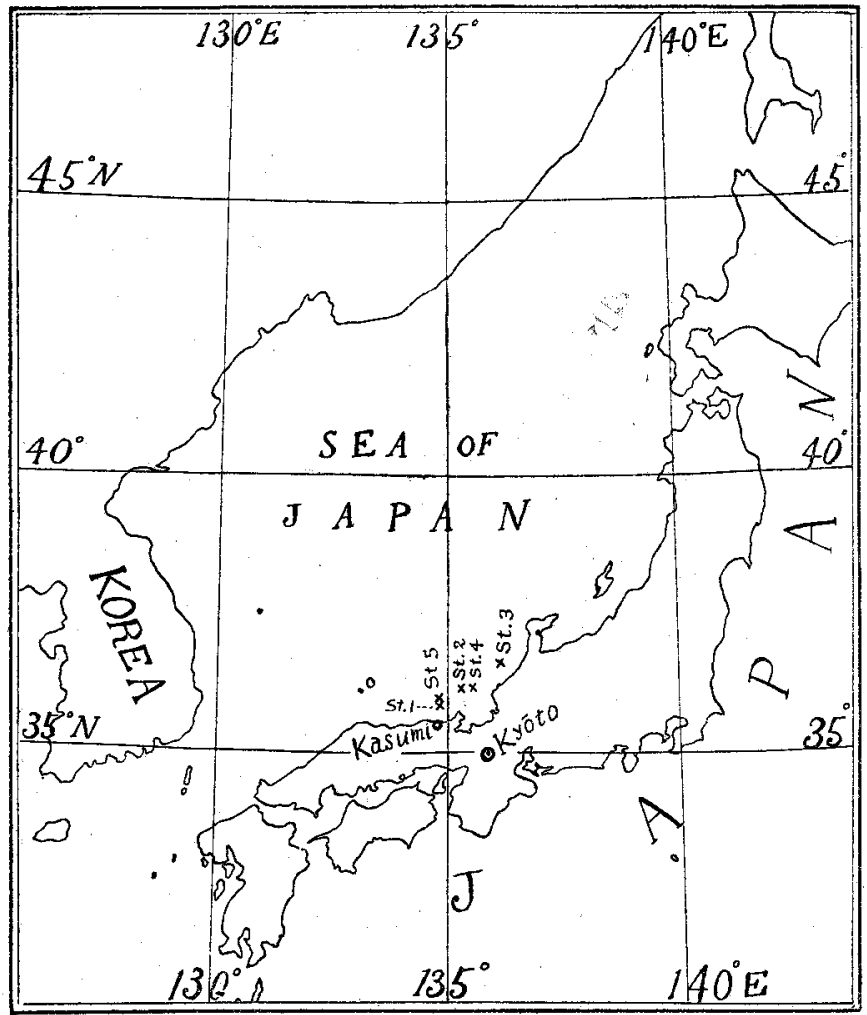

Publ. Seto Mar. Biol. Lab., II (2), 1952. (Article 15) 
mals in samples hauled from $310 \mathrm{~m}$ to the surface, while there were found only warm water forms living in Tsushima Current in samples hauled in the surface layer shallower than $50 \mathrm{~m}$. The same phenomenon was also observed on samples collected at stations 20-30 miles off San'in district during the period from June to August in the same year.

These observations seem to suggest the existence of the flow of the socalled "inherent water of Japan Sea" under the warm water of Tsushima Current. And so, it may be very interesting to describe on the composition of zooplankton and give notes on some cold water plankton animals found during these surveys.

These plankton samples were hauled up from the deeper layer by a large closing net which was designed to catch the macroplankton living in deep water, $50 \mathrm{~cm}$ in diameter, $2 \mathrm{~m}$ in length and stretched with MüLiER's gauze No. 5 .

The composition of zooplankton will be shown in Table 1 , and that of Copepoda which occupies a great part of zooplankton will be shown in Table 2.

Table 1. Composition of Zooplankton. $(\%$ to the whole zooplankton)

\begin{tabular}{|c|c|c|c|c|c|}
\hline Sation & St. 1 & St. 2 & St. 3 & $\mathrm{SE.} 4$ & St. 5 \\
\hline $\begin{array}{l}\text { Lat. (N) } \\
\text { Long. (E) }\end{array}$ & $\begin{array}{r}36-00.0 \\
134-40.0\end{array}$ & $\begin{array}{r}36-03.0 \\
135-13.0\end{array}$ & $\begin{array}{r}36-39.0 \\
135-46.0\end{array}$ & $\begin{array}{r}36-16.4 \\
135-27.8\end{array}$ & $\begin{array}{r}36-09.6 \\
134-40.0\end{array}$ \\
\hline Date & May 25 & June 21 & July 18 & Ju'y 31 & Aug. 2 \\
\hline Haul. Depith (m) & $310-0$ & $300-1.40$ & $400-320$ & $400-230$ & $500-255$ \\
\hline Hydromedusae & 0.2 & 3.7 & 7.7 & 1.2 & 1.4 \\
\hline Copepoda & 87.8 & 78.3 & 88.3 & 93.8 & 84.2 \\
\hline Ostracoda & 3.6 & 0.5 & - & - & 8.2 \\
\hline Schizopoda & 0.8 & - & 1.4 & 1.8 & 3.3 \\
\hline Amphipoda & 0.1 & 0.0 & 0.1 & 1.0 & 1.1 \\
\hline Pteropoda & 2.9 & 4.8 & 1.4 & 0.5 & - \\
\hline Chaetognatha & 0.3 & 0.0 & 0.3 & 0.0 & 0.3 \\
\hline Tunicata & 4.3 & 11.1 & 1.4 & 0.0 & 0.0 \\
\hline Others & - & 1.6 & - & 1.7 & 1.5 \\
\hline
\end{tabular}


Tab'e 2. Composition of Copepoda. (\% to the whole Copepoda)

\begin{tabular}{l|r|r|r|r|r}
\hline \multicolumn{1}{c|}{ Station } & St. 1 & St. 2 & St. 3 & St. 4 & St. 5 \\
\hline Calanus plumehrus & 0.3 & 0.6 & 0.3 & 1.3 & 1.4 \\
Eucalanus giesbrechti & 0.0 & - & 0.3 & 0.2 & 0.2 \\
Euchaeta japonica & 0.0 & - & 0.0 & 0.3 & 0.5 \\
Metridia lucens & 1.6 & - & 1.6 & 16.9 & 22.1 \\
Oithona sp. & 59.2 & 12.2 & 67.4 & 54.6 & 22.5 \\
Oncati sp. & 0.0 & 4.3 & 3.1 & 3.9 & 14.2 \\
Others & 38.9 & 82.9 & 27.6 & 23.3 & 39.7 \\
\hline
\end{tabular}

Above all, the most important species, excepting copepods, are Aglantha digitale HAECKEL in Hydromedusa, Concoecia sp. in Ostracoda, Euphausia pacifica HANSEN in Schizopoda, Limacina helicina and Clione limacina in Pteropoda, Sagitia elegans VERRIL in Chaetognatha and Oikopleura sp. in Tunicata. Besides the species listed in Table 2, the following species of copepods are noticeable: Calanus cristatus KRöYER was found one or two individuals at three stations, Scorechithricella minor (BRADY) and some individuals of Bradyiditus armatus were found at St. 5 .

All of these cold water species, found commonly in the surface water of Liman Current and "Oyashio", are never seen in samples hauled up from the layer shallower than $50 \mathrm{~m}$. The sample from St. 2 (off Kyôga-misaki) contains a number of warm water forms as in surface hauls, besides the cold water forms.

In the following, a brief note is given on each noticeable cold water form, although the details on Crustacea is reserved in a future paper.

a) Aglantha digitale, the most important species in cold water Hydromedusae in Japan, occurred always with some Siphonophora in a considerable number at all stations excepting St. 2, where no Siphonophora was found.

b) Limacinx helicina, a cold water pteropod, was abundantly found at St. 2 in August. In other stations, it was not so matured as in St. 2, and in rather small numbers.

c) Clione limacina, a cold water pteropod, occurred in a few number in samples from St. 1.

d) Sagitta elegans was found plentifully in the deeper layer off Kasumi in May. but in August it was rather rare. In other stations, this species was found mingled with some warm oceanic species and in a few number. Some individuals fully matured, but most of them were immature. In identifying these young indi- 
viduals I am indebted much to Dr. T. Tozioka of the Seto Marine Biological Laboratory.

Besides, the occurrence of Oikopleura labradoriensis LoHMANN in the deep waters near the New Yamoto Bank (TokiokA, 1951) must be noticed.

Thus, it may be summarized safely from the above-mentioned data that the deep waters off San'in district contains many cold water animal planktons, and this phenomenon is especially remarkable at stations off Kasumi.

Before conclusion, the author wishes to express his hearty thanks to Dr. T. TokiokA for his valuable advices and generous help throughout this work, and also he is indebted to Mr. S. FUKASE of Nagasaki Marine Observatory, and to the crew on board the "Kuroshio-maru".

\section{LITERATURE}

NAKAI, Z. (1942): The chemical composition, volume, weight and size of the important marine plankton, Jour. Ocean. Soc. Japan, Vol. I, Nos. 1 \& 2, pp. 45-55. (in Japanese)

TANAKA, O. (1938): Notes on Calanus cristatus Kröyer, Japan. Jour. Zool. Vol. VII, pp. 599601.

TOKIOKA, T. (1951): Pelagic Tunicates and Chaetognaths collected during the cruises to the New Yamato Bank in the Sea of Japan, Publ. Seto Mar. Biol. Lab., Vol. II, No. 1, pp. 1-25. 